\title{
Fatores de risco para mumificação fetal e natimortalidade em granjas tecnificadas de suínos*
}

\author{
VLADIMIR FARIAS BORGES \\ Ivo Wentz (Orientador - UFRGS) \\ Fernando Pandolfo Bortolozzo(Co-orientador - UFRGS) \\ Mari Lourdes Bernardi (Co-orientadora - UFRGS)
}

Banca: David Driemeier (UFRGS), Ilmo Wentz (UFSM), Paulo Alberto Lovatto (UFSM)

Um dos parâmetros mais utilizados para a mensuração da produtividade em suínos é o número de leitões desmamados por fêmea ao ano. A importância da mortalidade fetal tem aumentado devido ao aumento na taxa de ovulação e provável limitação da capacidade uterina. As perdas fetais, juntamente com a mortalidade na maternidade, estão entre as maiores causas de perdas na suinocultura. Os objetivos do trabalho foram verificar os fatores de risco para mumificação fetal e natimortalidade em 4 granjas tecnificadas. Para fins de análise, os dados de 565 partos foram separados em 2 grupos de granjas com características de ordem de parto (OP) semelhantes, sendo a média de 2,81 e 4,45 partos no grupo A e grupo $\mathrm{B}$, respectivamente. Os leitões e as placentas foram pesados individualmente para obtenção do índice de produção placentária (IPP). A análise dos possíveis fatores de risco para natimortalidade e mumificação fetal foi feita pela regressão logística multivariada. As taxas de natimortos e de mumificados foram de 4,9\% e 4,0\% e de 6,2\% e 2,8\%, nos grupos A e B, respectivamente. O percentual de fêmeas com natimortos foi de 39,6 (110/278) no grupo A, e 44,6 (128/287) no grupo B. As fêmeas com mumificados representaram 37,4\% (104/278) e 25,4\% (73/287) nos grupos A e B, respectivamente. Fêmeas com mais de 12 leitões apresentaram maiores chances de natimortalidade, no grupo A, ou de mumificação, em ambos os grupos. Fêmeas com $\mathrm{OP}>5$ tiveram maior risco de natimortalidade, em comparação àquelas de OP 2 a 5 , no grupo A. Maior risco de mumificados ocorreu nas fêmeas de OP > 5 e nas leitoas, no grupo B. O peso da leitegada foi fator de risco para natimortalidade, sendo observado maior percentual de fêmeas com natimortos em leitegadas acima de $18 \mathrm{~kg}$ ou em leitegadas leves ( $<13 \mathrm{~kg})$, mas com leitões de baixo peso médio. Fêmeas com partos longos ( $>3 \mathrm{~h}$ ) tiveram maior chance de natimortalidade no grupo B. As fêmeas com mumificados, do grupo B, apresentaram maior risco de natimortalidade. No grupo B, fêmeas com menor IPP tiveram maior chance de mumificação, em relação àquelas com maior IPP. Os manejos associados ao parto, como indução, uso de ocitocina ou auxílio manual ao parto não foram fatores de risco para natimortalidade.

Descritores: mortalidade fetal, mumificados, leitões natimortos, partos, ordem de parto, tamanho da leitegada, placenta, peso ao nascer, ocitocina, toque, indução. 


\title{
Risk factors for stillbirth and fetal mummification in commercial swine farms**
}

\author{
VLADIMIR FARIAS BORGES \\ Ivo Wentz (Adviser - UFRGS) \\ Fernando Pandolfo Bortolozzo(Co-adviser - UFRGS) \\ Mari Lourdes Bernardi (Co-adviser - UFRGS)
}

Committee: David Driemeier (UFRGS), Ilmo Wentz (UFSM), Paulo Alberto Lovatto (UFSM)

One of the parameters most used to measure the productivity in swine is the number of pigs weaned/female/year. The fetal mortality importance has increased due to the higher ovulation rate and probable limitation of the uterine capacity. The fetal losses and pre-weaning mortality are among the most important causes of losses in the commercial swine herds. The objectives of the study were to verify the risk factors for fetal mummification and stillbirth in 4 commercial swine farms. For the analysis, data of 565 farrowings were separated in 2 groups (each group with 2 farms) with similar parity (OP) characteristics, 2.81 and 4.45 parities/female in group A and group B, respectively. The pigs and the their placental were individually weighted to obtain the production placental index (IPP). The analysis of the possible risk factors for stillbirth and fetal mummification was made by the multivariable logistic-regression. The stillbirth and mummified rates were of $4.9 \%$ and $4.0 \%$ and of $6.2 \%$ and $2.8 \%$, in the groups A and B, respectively. The percentage of females with stillbirth was of 39.6 (110/278) in the group A, and 44.6 (128/287) in the group B. The females with mummified foetuses represented 37.4\% (104/ 278 ) and $25.4 \%$ (73/287) in groups A and B, respectively. Females with more than 12 piglets/litter presented higher risk for stillbirth occurrence, in the group A, or for mummification in both groups. In the group A, females with OP $>5$ had greater risk for stillbirth presence in comparison to those of OP 2 to 5. In group B, higher risk of mummified occurrence happened in females of OP $>5$ and gilts. The litter birth weight was a risk factor to stillbirth, being observed higher percentage of females with stillbirth in heavier litters $(>18 \mathrm{~kg})$ or in lighter litters $(\leq 13 \mathrm{~kg})$, but with piglets of low weight. Females with prolonged farrowing $(>3 \mathrm{~h}$ ) had higher stillbirth occurrence, in the group B. The females in the group B that had mummified foetuses presented higher stillbirth risk. In the group B, females with lower IPP had a higher risk of mummification compared to those with higher IPP. None of the farrowing management, as induction, oxytocin use or vaginal palpation were risk factors to stillbirth occurrence.

Key words: foetal mortality, mummies, stillbirth piglets, farrowing, parity, litter size, placenta, birth weigth, oxytocin, vaginal palpation, induction.

Presented: 14 March 2004

**Master's Thesis \# 372 (Field: Animal Reproduction). 70p. Graduate Program in Veterinary Sciences, Faculdade de Veterinária, Universidade Federal do Rio Grande do Sul (UFRGS), Porto Alegre/Brazil. CORRESPONDENCE: V.F. Borges [vladimir.fb@ terra.com.br ]. 